\title{
Down-regulation of tumor suppressor gene PTEN, overexpression of p53, plus high proliferating cell nuclear antigen index predict poor patient outcome of hepatocellular carcinoma after resection
}

\author{
TSUNG-HUI HU ${ }^{1}$, CHIH-CHI WANG ${ }^{2}$, CHAO-CHENG HUANG ${ }^{3}$, CHAO-LONG CHEN ${ }^{2}$, \\ CHAO-HUNG HUNG ${ }^{1}$, CHIEN-HUNG CHEN ${ }^{1}$, JING-HOUNG WANG ${ }^{1}$, SHENG-NAN LU ${ }^{1}$, \\ CHUAN-MO LEE ${ }^{1}$, CHI-SIN CHANGCHIEN ${ }^{1}$ and MING-HONG TAI ${ }^{4}$
}

\begin{abstract}
Division of Hepato-Gastroenterology, Departments of ${ }^{1}$ Internal Medicine, ${ }^{2}$ Surgery, ${ }^{3}$ Pathology, Chang Gung Memorial Hospital-Kaohsiung Medical Center, Chang Gung University College of Medicine; ${ }^{4}$ Department of Medical

Education and Research, Kaohsiung Veterans General Hospital, Kaohsiung, Taiwan
\end{abstract}

Received June 14, 2007; Accepted July 16, 2007

\begin{abstract}
We aimed to evaluate the interaction of two tumor suppressor genes PTEN and p53 and their relationship with cell cycle protein proliferating cell nuclear antigen (PCNA) in hepatocellular carcinoma (HCC). A total of 124 resected HCC paraffin specimens were collected from 1987 to 1999 for immunohistochemistry. Expression of PTEN, p53 and PCNA in $\mathrm{HCC}$ were analyzed for clinicopathologic correlation. The study revealed decreased or absent PTEN immunostaining (PTEN down-regulation) in $42.7 \%$ and positive p53 (p53+) immunostaining in $41.9 \%$ of HCC. There was a positive correlation between PTEN down-regulation and p53 (+) $(\mathrm{P}=0.001)$. PTEN down-regulation or p53 $(+)$ correlated with increased HCC dedifferentiation, advanced pathologic stages and high PCNA labeling index $(\mathrm{LI})$ of tumors $(\mathrm{P}<0.05)$. Patients with either PTEN down-regulation, p53 (+), or high PCNA LI had shorter survival and higher recurrence rates than patients with intact PTEN expression, p53 (-), or low PCNA LI respectively $(\mathrm{P}<0.05)$. By combining the three genes, patients with all PTEN down-regulation $(+) / \mathrm{p} 53(+) /$ high PCNA LI had the shortest overall survival $(\mathrm{P}<0.001)$ and the highest recurrence rates $(\mathrm{P}<0.001)$, followed by patients with two, one and none of three events accordingly. Combination of PTEN/p53/PCNA represented an independent prognostic factor for tumor recurrence and disease-specific survival $(\mathrm{P}<0.05)$. In conclusion, the down-regulated PTEN expression and p53 over-expression are involved in the
\end{abstract}

Correspondence to: Dr Ming-Hong Tai, Department of Medical Education and Research, Room 3654, Kaohsiung Veterans General Hospital, 386 Ta-Chung 1st Road, Kaohsiung 813, Taiwan

E-mail: mhtai@isca.vghks.gov.tw

Key words: PTEN, p53, proliferating cell nuclear antigen, prognosis, hepatocellular carcinoma pathogenesis of HCC. They correlate with high PCNA expression, HCC de-differentiation and advanced HCC stages. A combination of the three genes predicts patient outcome more powerfully than any of the individual genes.

\section{Introduction}

Hepatocellular carcinoma (HCC) is one of the most common malignant tumors worldwide $(1,2)$. Hepatocarcinogenesis is considered a multifactorial and multistep process involving different genetic alteration that ultimately leads to malignant transformation of the hepatocytes. Several investigations demonstrated chromosomal allelic losses in HCC tissues, suggesting the deletion or alteration of tumor suppressor genes, which may play a role in the development and progression of HCC. In HCC, loss of heterozygosity (LOH) was reported on chromosomes 1p, 4q, 5q, 8p, 10q, 11p, 13q, $16,17 p$, and $22 q$ (3). At present, only few tumor suppressor genes located in these deleted regions were clearly involved in a significant subset of HCC, like $p 53$ gene (17q13), $R b$ gene (13q14) and $A P C$ gene (5q21). Among these, the p53 gene is the most widely studied. The p53 gene is mutated in about $30 \%$ of HCC worldwide (3) and plays an important role in the genesis or progression of HCC. The prognostic role of structural abnormality in the p53 gene for $\mathrm{HCC}$ has also been previously deciphered (4-8). Furthermore, the p53 gene regulates expression of proliferating cell nuclear antigen (PCNA) in HCC $(9,10)$. PCNA is a nuclear protein, which is closely related to the cell cycle regulation being an auxiliary molecule for DNA polymerase- $\delta$ (11). PCNA can be applied as a useful marker for detecting proliferating cells and correlated to histologic characteristics and prognosis in HCC $(12,13)$.

A newly identified novel tumor suppressor gene, PTEN (also known as MMACl or TEP1), is located on human chromosome 10q23 (14-16). Mutation of PTEN is a common event in the advanced stage of diverse human cancers, occurring in about $70 \%$ of glioblastoma, $50 \%$ of endometrial 
carcinoma, $50 \%$ of prostate carcinoma and $30 \%$ of melanoma (17). The 403-amino acid PTEN protein encodes dual specificity protein phosphatases. The two major substrates for PTEN are phosphatidylinositol triphosphate $\left(\mathrm{PIP}_{3}\right)$ phospholipids and oncogene Akt/PKB. Both are important signal transducers for growth, survival and proliferation of cells (18). Loss of PTEN allele was identified in 20 to $30 \%$ of HCC cases $(19,20)$. A study by cDNA microarray analysis indicated that the levels of PTEN transcripts decreased in a significant number of HCC patients (21). However, DNA sequencing analysis indicated that mutations in the PTEN gene rarely occurred in HCC specimens $(19,20,22,23)$. Previously, we provided new evidence for loss of PTEN function which participates in the HCC progression and poor prognosis (24).

Other studies revealed that p53 regulated PTEN expression. Loss of p53 function disrupts p53-mediated PTEN transcription $(25,26)$. In addition, PTEN protects p53 from Mdm2 and sensitizes cancer cells to chemotherapy (27). However, the interaction between PTEN, p53 and cell cycle protein PCNA during HCC progression remains to be elucidated. To gain further insight, the status of PTEN, p53 and PCNA protein expression was analyzed in $124 \mathrm{HCC}$ specimens by immunohistochemistry. We applied a combination of PTEN, p53 and PCNA expression for prognostic prediction of HCC patients in the present study and found that the combination of the three genes predicted patient outcome more powerfully than the individual genes.

\section{Materials and methods}

Resected HCC specimens. A total of $124 \mathrm{HCC}$ paraffin specimens were collected by surgical resection at the Department of Pathology at Kaohsiung Chang Gung Memorial Hospital from January 1987 to December 1999. All the HCC patients were diagnosed with resectable tumor(s) after liver biochemical tests and complete imaging studies such as sonography, computed tomography and/or angiography. Patients who died due to post-surgical complications or hepatic failure were excluded from this study. The closing date was the follow-up to December 31, 2005. The durations of the follow-up are shown in months. Hepatitis markers, serum $\alpha \mathrm{FP}$ levels and other clinical parameters of HCC patients were also recorded. All the HCC specimens consisted of both tumor and adjacent non-tumor tissue. Tumor sizes were recorded as the largest diameter in the specimen. Background of the non-tumor part was characterized as cirrhotic or non-cirrhotic. The differentiated states of HCC were divided into three groups as well (grade I carcinoma of Edmondson-Steiner classification), moderate (grade II carcinoma of Edmondson-Steiner classification) and poor (grade III and IV carcinoma of Edmondson-Steiner classification). The pathological stages of HCC were classified according to the staging system by the International Union Against Cancer with minor modification: stage I, encapsulated, without evidence of liver or vascular invasion; stage II, unencapsulated or capsulated and with liver invasion, but without vascular invasion; stage III, invasion of small vessels in the tumor capsule or focal invasion of portal vein branches close to the tumor; stage IV, invasion of portal vein in distal liver ( $1 \mathrm{~cm}$ away from the tumor capsule),

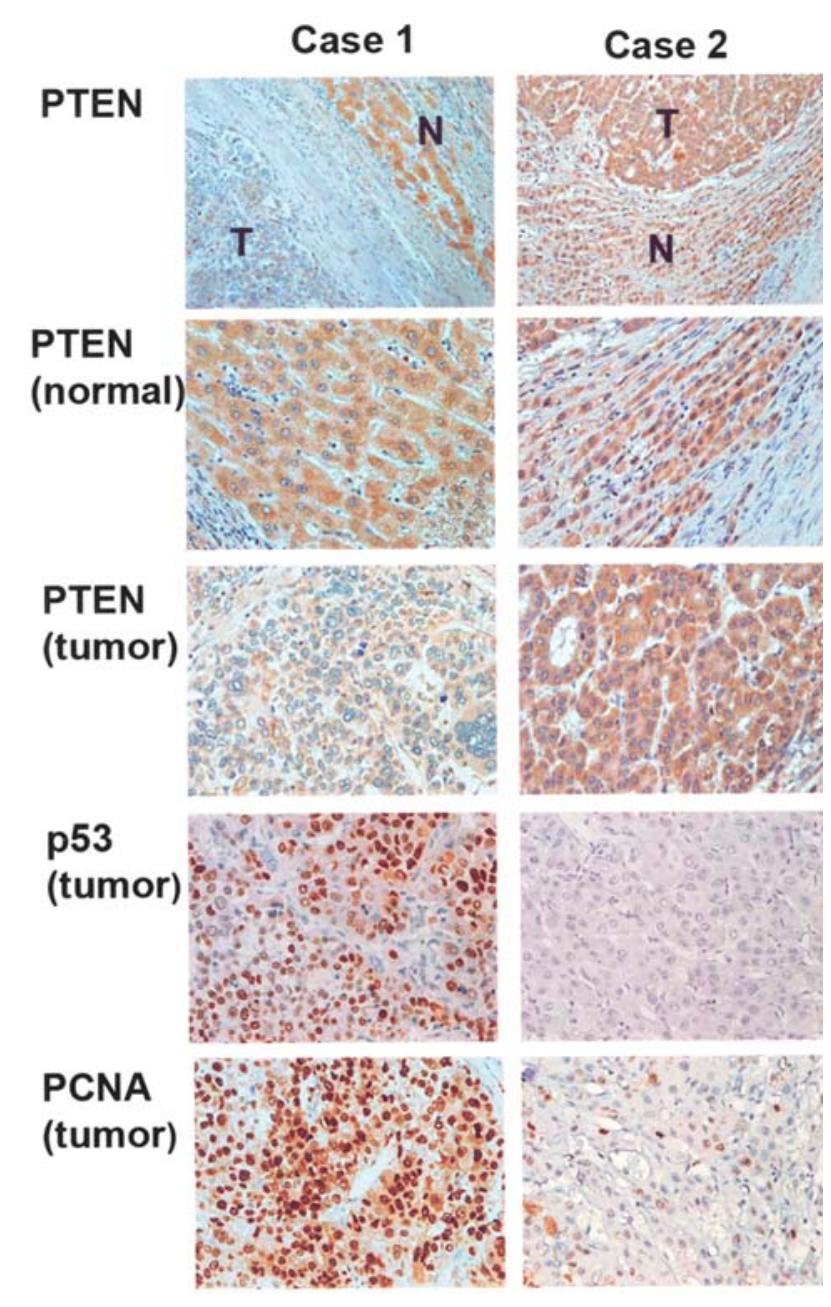

Figure 1. Immunohistochemical studies of PTEN, p53 and PCNA in two HCC cases. Case 1 exhibits PTEN down-regulation (T: tumor, $<\mathrm{N}$ : normal), p53 over-expression and high PCNA index whose tumor recurred early after resection and the patient died of HCC. In contrast, case 2 shows an intact PTEN $(\mathrm{T}=\mathrm{N})$, negative p53 and low PCNA expression in the tumor and who has survived for a longer period without disease recurrence after resection. (x200 magnification).

branches of the major portal vein, common bile duct, or perforation into visceral peritoneum.

Immunohistochemistry. The paraffin sections from HCC specimens were deparaffinized, blocked with $3 \%$ hydrogen peroxide for $10 \mathrm{~min}$ and subjected to antigen retrieval with microwave in $0.01 \mathrm{M}$ citrate buffer for $15 \mathrm{~min}$. The slides were then washed twice with PBS, incubated with polyclonal PTEN antibodies (1:100 dilution, $2 \mu \mathrm{g} / \mathrm{ml})(24)$, p53 antibodies (1:100 dilution; Dako) and proliferating cell nuclear antigen (PCNA) antibodies (1:100; M0879, Dako) for $30 \mathrm{~min}$, then detected with peroxidase conjugate using the polymer detection system (Zymed Cat. No. 87-89431) for $30 \mathrm{~min}$. The antibody staining was visualized with 3,3-diaminobenzidine tetrahydrochloride (DAB; Sigma, St. Louis, MO) in 0.1 M Tris $\mathrm{pH} 7.2$, containing $0.01 \% \mathrm{H}_{2} \mathrm{O}_{2}$. The section slides were counterstained with Gill's hematoxylin, dehydrated and mounted.

Immunohistochemical scoring. The intensities of immunostaining of clinical samples were expressed as a labeling index 
Table I. Correlation of PTEN expression and clinicopathological parameters of HCC.

\begin{tabular}{|c|c|c|c|}
\hline & $\begin{array}{c}\text { PTEN } \\
\text { down-regulation (-) } \\
(\mathrm{n}=71)(57.3 \%)\end{array}$ & $\begin{array}{c}\text { PTEN } \\
\text { down-regulation }(+) \\
(\mathrm{n}=53)(42.7 \%)\end{array}$ & $\mathrm{P}$ \\
\hline Grades & & & $0.007^{\mathrm{a}, \mathrm{d}}$ \\
\hline Well (n=28) & 20 & 8 & \\
\hline Moderate $(n=62)$ & 38 & 24 & \\
\hline Poor $(n=34)$ & 13 & 21 & \\
\hline Cirrhosis & & & $\mathrm{NS}(0.12)^{\mathrm{a}}$ \\
\hline No $(n=47)$ & 31 & 16 & \\
\hline Yes $(n=77)$ & 40 & 37 & \\
\hline Gender & & & $\mathrm{NS}(0.29)^{\mathrm{a}}$ \\
\hline Female $(n=24)$ & 16 & 8 & \\
\hline Male $(n=100)$ & 55 & 45 & \\
\hline $\mathrm{HBV}$ & & & $\mathrm{NS}(0.14)^{\mathrm{a}}$ \\
\hline Without $(\mathrm{n}=35)$ & 24 & 11 & \\
\hline With $(\mathrm{n}=83)$ & 45 & 38 & \\
\hline $\mathrm{HCV}$ & & & $\mathrm{NS}(0.13)^{\mathrm{a}}$ \\
\hline Without $(\mathrm{n}=88)$ & 48 & 40 & \\
\hline With $(n=30)$ & 21 & 9 & \\
\hline Capsule & & & $\mathrm{NS}(0.22)^{\mathrm{a}}$ \\
\hline Without $(\mathrm{n}=67)$ & 42 & 25 & \\
\hline With $(\mathrm{n}=57)$ & 29 & 28 & \\
\hline Pathological stages & & & $0.01^{\mathrm{a}, \mathrm{d}}$ \\
\hline $\mathrm{I}+\mathrm{II}(\mathrm{n}=61)$ & 42 & 19 & \\
\hline III+IV (n=63) & 29 & 34 & \\
\hline P53 & & & $0.001^{\mathrm{a}, \mathrm{d}}$ \\
\hline Negative $(n=72)$ & 50 & 22 & \\
\hline Positive $(n=52)$ & 21 & 31 & \\
\hline PCNA (LI) & $67.2 \pm 24.3$ & $76.9 \pm 18.7$ & $0.014^{\mathrm{b}, \mathrm{d}}$ \\
\hline Tumor size $(\mathrm{cm})$ & $6.11 \pm 3.97$ & $6.61 \pm 3.67$ & $\mathrm{NS}(0.48)^{\mathrm{b}}$ \\
\hline$\alpha \mathrm{FP}(\mathrm{ng} / \mathrm{ml})$ & $40.5(2-42350)$ & $267(3-70955)$ & $0.001^{\mathrm{c}, \mathrm{d}}$ \\
\hline Age (age) & $56.0 \pm 12.8$ & $55.5 \pm 12.9$ & $\mathrm{NS}(0.82)^{\mathrm{b}}$ \\
\hline
\end{tabular}

$\alpha \mathrm{FP}$, alpha fetoprotein; HBsAg, hepatitis B surface antigen; HCV Ab, hepatitis C antibody; PCNA, proliferating cell nuclear antigen; NS, not significant. Categorical data were compared by: ${ }^{\mathrm{a}} \mathrm{x}^{2} \mathrm{q} 2$ test; ${ }^{\mathrm{b}} \mathrm{Student}$ 's $\mathrm{t}$-test; ${ }^{\mathrm{c}}$ Mann-Whitney $\mathrm{U}$ test; ${ }^{\mathrm{d}}$ statistically significant $(\mathrm{p}<0.05)$.

(or scores) by pathologists. The putative normal liver tissue was collected from individuals with traumatic internal bleeding by partial hepatectomy and used as a positive control for PTEN staining. As a negative control, the normal liver tissue was stained with preimmune rabbit serum $(1: 100$ dilutions). PTEN intensities in both tumor and non-tumor parts were graded as none or weak, intermediate or strong. 'PTEN down-regulation' was defined as the lower PTEN scores in HCC tissues than that in their adjacent normal tissue. Since staining variation usually occurred especially in the non-neoplastic liver tissue between the peritumoral region and the region far away from the tumor, only the peritumoral liver tissue was scored as the non-tumor part. The p53 expression in HCC samples was scored as previously described $(4,5)$. Briefly, expression of p53 in tumor tissues was scored based on the percentage of cells with positive nuclear staining. 'P53 positive (+)' was defined as positive nuclear p53 staining $\geq 10 \%$. Whereas 'p53 negative (-)' was for cases whose positive nuclear p53 staining was $<10 \%$. The labeling index of nuclear PCNA was assessed as previously described (13). The sections were scanned at a low power to determine the areas that were most evenly and heavily labeled. Regardless of staining intensity, the nuclear labeling index (LI) was expressed as the average percentage of cells with PCNA nuclear staining from five different high-power fields (x400 magnification). The LI of PCNA was further divided into two groups (high or low) by the ROC curve based on disease recurrence. The correlation between groups and clinicopathological features of HCC such as histological tumor grades (differentiation) and pathological stage, survival outcome, serum levels of $\alpha \mathrm{FP}$, cirrhotic background, hepatitis markers and tumor size were analyzed by statistical analysis.

We then further divided all patients into four groups for survival comparison based on the three factors of PTEN downregulation (+), p53 (+) and high PCNA LI. They are group 1: none of the three factors present; group 2: one of the three factors present; group 3: two of the three factors present; and group 4: all three factors present.

Statistical methods. Comparisons between groups of related samples were assessed by the Wilcoxon paired-sample test. 
Table II. Correlation of p53 expression and clinicopathological parameters of HCC.

\begin{tabular}{|c|c|c|c|}
\hline & $\begin{array}{c}\mathrm{p} 53(-) \\
(\mathrm{n}=72)(58.1 \%)\end{array}$ & $\begin{array}{c}\mathrm{p} 53(+) \\
(\mathrm{n}=52)(41.9 \%)\end{array}$ & $\mathrm{P}$ \\
\hline Grades & & & $0.006^{\mathrm{a}, \mathrm{d}}$ \\
\hline Well (n=28) & 22 & 6 & \\
\hline Moderate $(n=62)$ & 37 & 25 & \\
\hline Poor $(n=34)$ & 13 & 21 & \\
\hline Cirrhosis & & & NS $(0.07)^{\mathrm{a}, \mathrm{e}}$ \\
\hline No $(n=47)$ & 32 & 15 & \\
\hline Yes $(n=77)$ & 40 & 37 & \\
\hline Gender & & & $\mathrm{NS}(0.15)^{\mathrm{a}}$ \\
\hline Female $(n=24)$ & 17 & 7 & \\
\hline Male $(n=100)$ & 55 & 45 & \\
\hline $\mathrm{HBV}$ & & & $\mathrm{NS}(0.72)^{\mathrm{a}}$ \\
\hline Without $(\mathrm{n}=35)$ & 21 & 14 & \\
\hline With $(\mathrm{n}=83)$ & 47 & 36 & \\
\hline $\mathrm{HCV}$ & & & $\mathrm{NS}(0.76)^{\mathrm{a}}$ \\
\hline Without $(\mathrm{n}=88)$ & 50 & 38 & \\
\hline With $(n=30)$ & 18 & 12 & \\
\hline Capsule & & & $\mathrm{NS}(0.41)^{\mathrm{a}}$ \\
\hline Without $(n=67)$ & 37 & 30 & \\
\hline With $(n=57)$ & 36 & 21 & \\
\hline Pathological stages & & & $0.017^{\mathrm{a}, \mathrm{d}}$ \\
\hline $\mathrm{I}+\mathrm{II}(\mathrm{n}=61)$ & 42 & 19 & \\
\hline III+IV (n=63) & 30 & 33 & \\
\hline PTEN & & & $0.001^{\mathrm{a}, \mathrm{d}}$ \\
\hline Down (-) $(\mathrm{n}=71)$ & 50 & 21 & \\
\hline Down $(+)(n=53)$ & 22 & 31 & \\
\hline PCNA (LI) & $64.8 \pm 25.7$ & $80.4 \pm 12.7$ & $<0.001^{\mathrm{b}, \mathrm{d}}$ \\
\hline Tumor size $(\mathrm{cm})$ & $6.13 \pm 3.85$ & $6.60 \pm 3.83$ & $\mathrm{NS}(0.51)^{\mathrm{b}}$ \\
\hline$\alpha \mathrm{FP}(\mathrm{ng})$ & $60(2-34250)$ & $97.5(3-70955)$ & $0.12^{\mathrm{c}}$ \\
\hline Age (age) & $57.4 \pm 11.8$ & $53.6 \pm 13.9$ & $\mathrm{NS}(0.10)^{\mathrm{b}}$ \\
\hline
\end{tabular}

$\alpha \mathrm{FP}$, alpha fetoprotein; HBsAg, hepatitis B surface antigen; HCV Ab, hepatitis C antibody; PCNA, proliferating cell nuclear antigen; NS, not significant. Categorical data were compared by: ${ }^{\mathrm{a}} \mathrm{x}^{2}$ test; ${ }^{\mathrm{b} S t u d e n t}$ 's $\mathrm{t}$-test; ${ }^{\mathrm{c}}$ Mann-Whitney $\mathrm{U}$ test; ${ }^{\mathrm{d}}$ statistically significant $(\mathrm{p}<0.05) ;{ }^{\mathrm{e}}$ borderline significant.

Comparisons between groups of independent samples were assessed by the student's t-test, one-way ANOVA, MannWhitney $\mathrm{U}$ test or the Kruskal-Wallis test. The associations between categorical variables were assessed using the Chisquare test or Fisher's Exact test. Survival rates were calculated by the Kaplan-Meier methods and the difference in survival was compared with the log-rank test. The influence of various clinicopathological features on overall survival was assessed by the Cox proportional hazard model. A p-value $<0.05$ was considered statistically significant.

\section{Results}

Clinical parameters of HCC patients. The surgically resected specimens were collected from $124 \mathrm{HCC}$ patients consisting of 100 males and 24 females. The ages ranged from 25 to 81 years, with a mean age of $55.8 \pm 11.9$ years. The overall survival rate was $45.9 \%(57 / 124)$ at the end of at least 6 years follow-up. Tumor sizes ranged from 1 to $20 \mathrm{~cm}$, with a mean size of $6.33 \pm 3.95 \mathrm{~cm}$. The differentiation extent in $\mathrm{HCC}$ samples were graded into three categories as well differentiated HCC (in 28 cases), moderately differentiated HCC (in 62 cases) and poorly differentiated HCC (in 34 cases). The tumor pathological stages were divided into stage I (in 19 cases), stage II (in 41 cases), stage III (in 37 cases) and stage IV (in 27 cases). In the background of non-tumor part, liver cirrhosis was found in 77 cases $(62 \%)$ and non-cirrhotic in 47 cases $(38 \%)$. The status of HBV and HCV in these HCC patients was examined. The HBsAg was detected in the sera of 83 patients $(67 \%)$ and anti-HCV was detected in 30 patients $(24 \%)$. Five patients $(4 \%)$ were positive for both $\mathrm{HBV}$ and $\mathrm{HCV}$, whereas ten patients $(8 \%)$ were negative for both markers. Six patients were of unknown hepatitis history.

PTEN, p53 and PCNA expression in HCC specimens. For immunohistochemical studies, PTEN antibodies were raised against recombinant PTEN protein (with a molecular weight of $\sim 45 \mathrm{kDa})$ and characterized by Western blot as well as histological analysis as previously described (24). The intensities of PTEN immunostaining in tumor and non-tumor regions were expressed as scores for statistical analysis. The expression of PTEN was mainly located at the cytoplasm and scanty at the nucleus. In 124 HCC specimens, 53 (42.7\%) cases had lower PTEN intensities in tumors than their 
Table III. Correlation between PCNA LI and clinicopathological parameters of HCCs.

\begin{tabular}{|c|c|c|c|}
\hline Variables & Category (n) & PCNA LI $(\%)$ & $\mathrm{P}$ \\
\hline Sex & $\begin{array}{l}\text { Male }(n=100) \\
\text { Female }(n=24)\end{array}$ & $\begin{array}{l}72.1 \pm 22.1 \\
68.4 \pm 20.2\end{array}$ & $\mathrm{NS}(0.48)^{\mathrm{a}}$ \\
\hline Cirrhosis & $\begin{array}{c}\text { With }(n=77) \\
\text { Without }(n=47)\end{array}$ & $\begin{array}{l}74.8 \pm 20.6 \\
48.3 \pm 27.5\end{array}$ & $0.029^{\mathrm{a}, \mathrm{g}}$ \\
\hline HBsAg & $\begin{array}{l}\text { Positive }(n=83) \\
\text { Negative }(n=35)\end{array}$ & $\begin{array}{l}74.5 \pm 20.8 \\
63.5 \pm 63.5\end{array}$ & $0.017^{\mathrm{a}, \mathrm{g}}$ \\
\hline $\mathrm{HCV} \mathrm{Ab}$ & $\begin{array}{l}\text { Positive }(n=30) \\
\text { Negative }(n=88)\end{array}$ & $\begin{array}{l}65.8 \pm 22.2 \\
73.1 \pm 73.1\end{array}$ & $\mathrm{NS}(0.13)^{\mathrm{a}}$ \\
\hline Grades & $\begin{array}{c}\text { Well }(n=28) \\
\text { Moderate }(n=62) \\
\text { Poor }(n=34)\end{array}$ & $\begin{array}{l}53.3 \pm 25.7^{\mathrm{d}} \\
75.5 \pm 19.6^{\mathrm{e}} \\
78.5 \pm 16.9^{\mathrm{d}}\end{array}$ & $<0.001^{\mathrm{b}, \mathrm{g}}$ \\
\hline Stages & $\begin{array}{c}\mathrm{I}+\mathrm{II}(\mathrm{n}=61) \\
\mathrm{III}+\mathrm{IV}(\mathrm{n}=63)\end{array}$ & $\begin{array}{l}63.7 \pm 21.8 \\
78.7 \pm 20.9\end{array}$ & $<0.001^{\mathrm{a}, \mathrm{g}}$ \\
\hline Tumor number & $\begin{array}{c}\text { Single }(n=94) \\
\text { Multiple }(n=30)\end{array}$ & $\begin{array}{l}70.2 \pm 24.4 \\
74.4 \pm 15.4\end{array}$ & $\mathrm{NS}(0.34)^{\mathrm{a}}$ \\
\hline PTEN & $\begin{array}{l}\text { Down }(-)(n=71) \\
\text { Down }(+)(n=53)\end{array}$ & $\begin{array}{l}67.2 \pm 24.3 \\
76.9 \pm 18.7\end{array}$ & $0.017^{\mathrm{a}, \mathrm{g}}$ \\
\hline P53 & $\begin{array}{l}\text { Positive }(n=52) \\
\text { Negative }(n=72)\end{array}$ & $\begin{array}{l}80.3 \pm 12.7 \\
64.8 \pm 25.7\end{array}$ & $<0.001^{\mathrm{a}, \mathrm{g}}$ \\
\hline $\begin{array}{l}\text { Age (year) } \\
\text { Tumor size (cm) } \\
\alpha \text { FP }(\mathrm{ng} / \mathrm{ml})\end{array}$ & & $\begin{array}{l}\text { CC: }-0.186 \\
\text { CC: } 0.204 \\
\text { CC: } 0.388\end{array}$ & $\begin{array}{c}0.039^{\mathrm{c}, \mathrm{g}} \\
0.023^{\mathrm{c}, \mathrm{g}} \\
<0.001^{\mathrm{c}, \mathrm{g}}\end{array}$ \\
\hline
\end{tabular}

$\alpha \mathrm{FP}, \alpha$ fetoprotein; HBsAg, hepatitis B surface antigen; HCV Ab, hepatitis C antibody; PCNA, proliferating cellular nuclear antigen; NS, not significant; CC, Correlation Coefficient. Categorical data was compared by: ${ }^{a}$ student's t-test; bone-way ANOVA (d-f: the difference in groups of the same letter is not

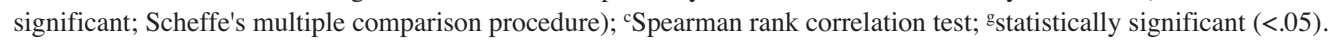

adjacent non-tumor tissues (mainly cytoplasm) (defined as PTEN down-regulation) (Fig. 1). Statistical analysis indicated that PTEN scores in non-tumor parts were significantly higher than that in tumor parts $(\mathrm{P}<0.001$, Wilcoxon paired-sample test). PTEN down-regulation in HCC was associated with increased grades $(\mathrm{P}=0.007)$, high PCNA LI ( $\mathrm{P}=0.014)$, high serum $\alpha \mathrm{FP}$ levels $(\mathrm{P}=0.001)$ and advanced pathologic stages $(\mathrm{P}=0.01)$ (Table I).

Subsequently, we analyzed p53 expression profile and compared it with that of PTEN in HCC specimens. Immunohistochemical studies demonstrated that p53 staining was sporadically localized in the nucleus of HCC tissues (Fig. 1). There was rare p53 immunostaining in non-tumor parts. In 124 HCC specimens, p53 positive (+) was found in 52 cases $(41.9 \%)$. Statistical analysis demonstrated that " $\mathrm{p} 53$ positive $(+)$ ' was associated with the increased grades $(\mathrm{P}=0.006)$, advanced pathologic stages $(\mathrm{P}=0.017)$, cirrhotic background $(\mathrm{P}=0.07$-marginal) and high PCNA LI $(\mathrm{P}<0.001)$ (Table II).

We then analyzed PCNA expression in HCC. Positive labeling index (LI) of PCNA was found at the nucleus, ranging from 5 to $98 \%$, with a mean of $71.3 \pm 22.5 \%$ (Fig. 1). The positive correlation between LI of PCNA and clinicopathological factors was extensive, such as cirrhotic background $(\mathrm{P}=0.029)$; increased grades $(\mathrm{P}<0.001)$; advanced pathological stage $(\mathrm{P}=0.002)$; young age patients $(\mathrm{P}=0.039)$; large tumor size $(\mathrm{P}=0.023)$; and high serum $\alpha \mathrm{FP}(\mathrm{P}<0.001)$ (Table III).
The correlation between PTEN, p53 and PCNA expressions in HCC specimens. Based on the individual gene expression, we further investigated the correlation between PTEN, p53 and PCNA expression in HCC. The results revealed that 31 $(58.5 \%)$ cases out of a total of 53 'PTEN down-regulation (+)' patients were 'p53 (+)', whereas only $21(29 \%)$ cases out of a total of 71 'PTEN down-regulation (-)' patients were 'p53 (+)'. There was a positive correlation between 'PTEN down-regulation (+)' and 'p53 (+)' (P=0.001, Table I, II). Moreover, patients bearing tumors with PTEN downregulation (+) or p53 (+) had higher PCNA LI than patients with PTEN down-regulation (-) or p53 (-) (Table I, II, III). These data suggested that down-regulated PTEN expression frequently occurred in HCC cells with defective p53 or vice versa in which PCNA expression was usually up-regulated.

Correlation of PTEN, p53 and PCNA expression with survival of HCC patients. Kaplan-Meier survival analysis indicated that patients with PTEN down-regulation (-), p53 (-), or low PCNA LI had a longer disease-specific survival than patients with PTEN down-regulation (+), p53 (+) or high PCNA LI $(\mathrm{P}<0.05)$ (Fig. 2A-C). After surgical resection, the mortality of HCC patients mainly resulted from recurrence of tumors. Kaplan-Meier analysis also indicated that patients with PTEN down-regulation (+), p53 (+), or high PCNA LI also had earlier tumor recurrence than their comparative groups $(\mathrm{P}<0.05)$ (Fig. 2D-F). We further combined three expression 
$\mathbf{A}$

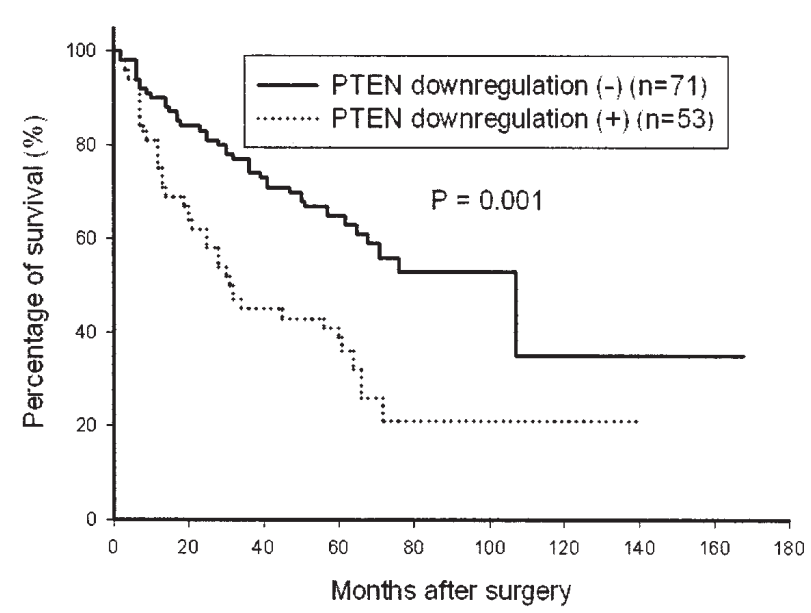

C

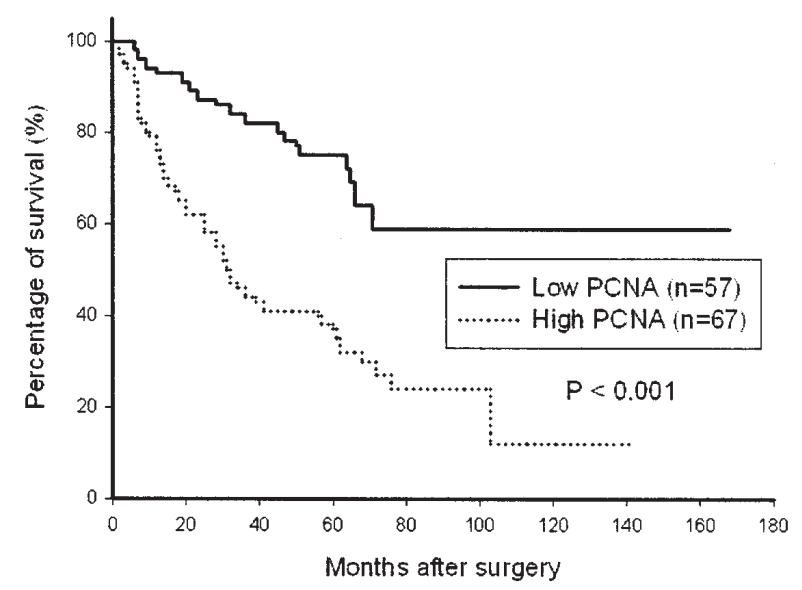

$\mathbf{E}$

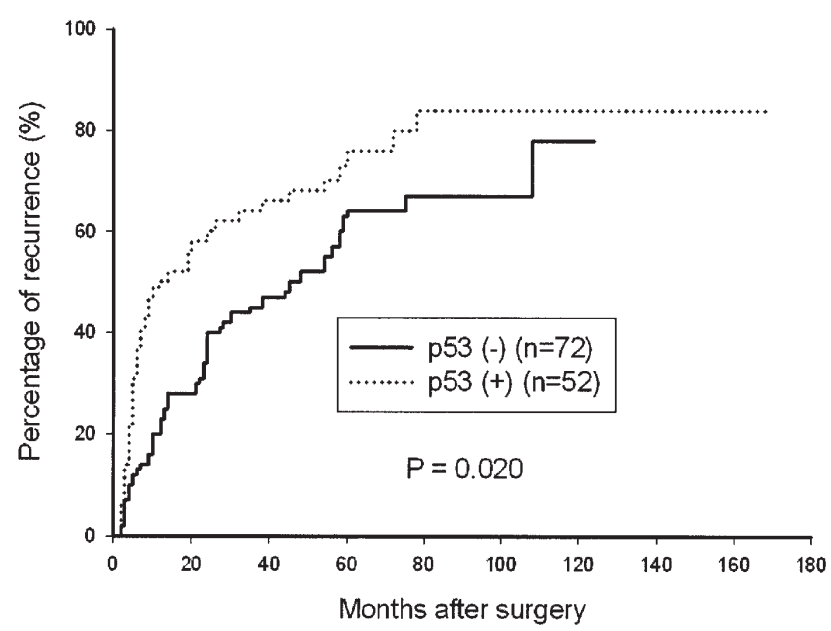

B

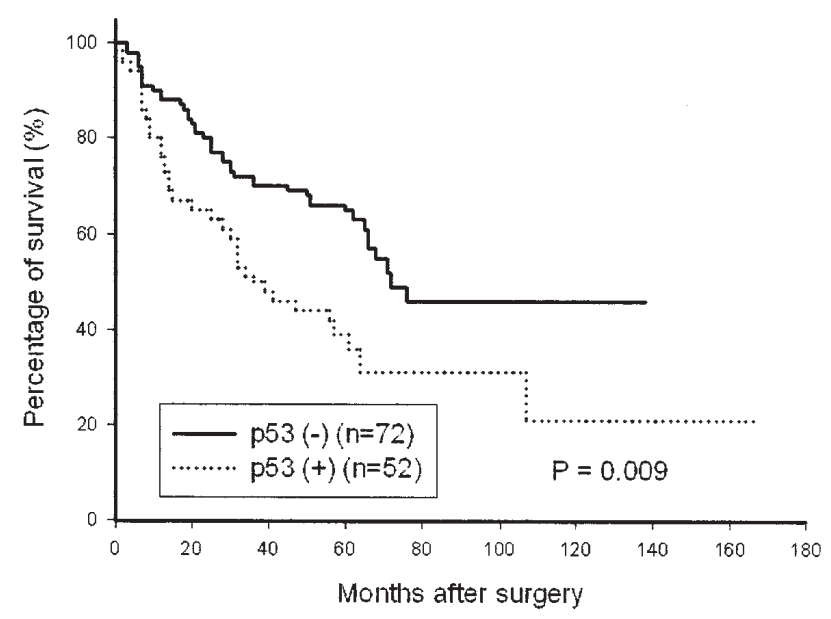

D

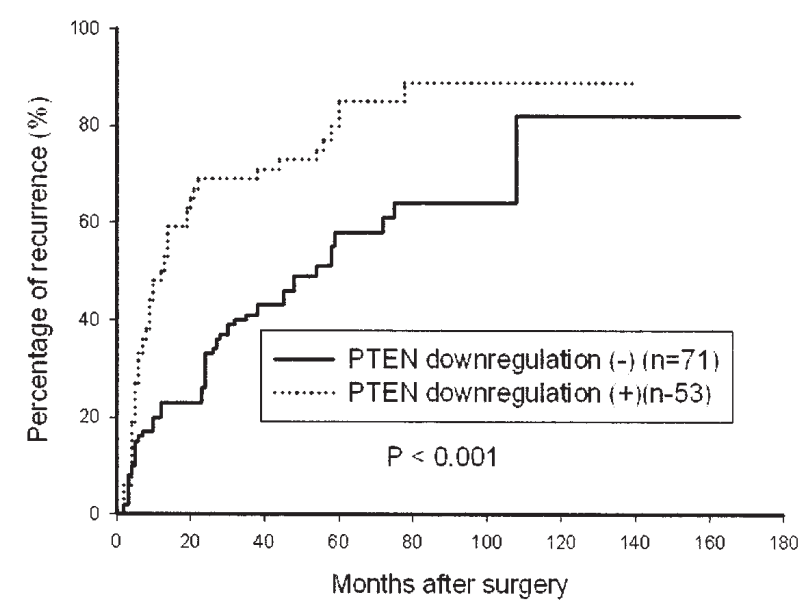

F

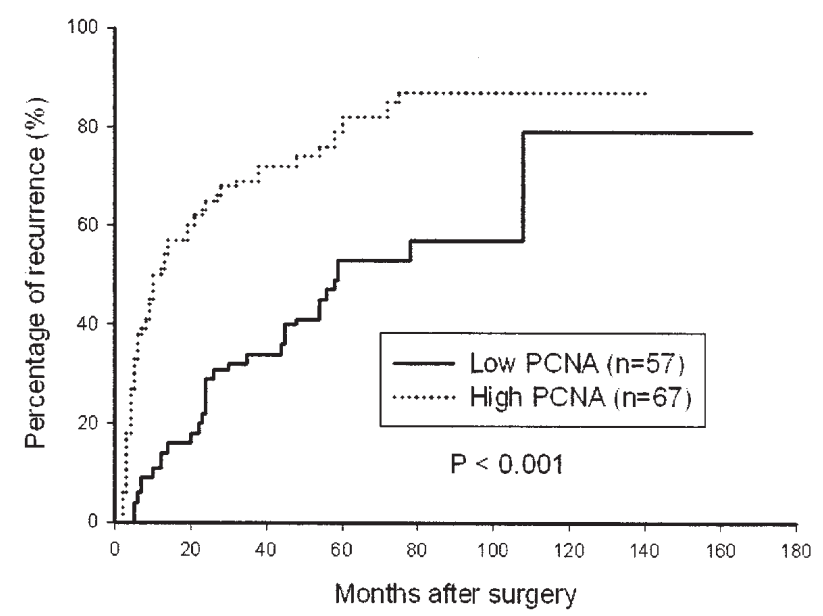

Figure 2. Kaplan-Meier analysis indicated that patients with either PTEN down-regulation (+), p53 (+), or high PCNA had shorter survival (A-C) and earlier disease recurrence (D-F) than patients with PTEN down-regulation (-), p53 (-), or low PCNA $(\mathrm{P}<0.05)$. n, the number of patients in each group.

patterns (PTEN down-regulation (+); p53 (+); high PCNA LI) to explore their prognostic significance in $\mathrm{HCC}$ and divided all the patients into four groups for comparison as i) none of three factors present (29 cases); ii) one of three factors present (33 cases); iii) two of three factors present (37 cases); and iv) all three factors present ( 25 cases). We found that patients in group I had the longest disease-specific survival and latest disease recurrence, followed by group II, group III and group IV accordingly $(\mathrm{P}<0.001$; Fig. $3 \mathrm{~A}$ and $\mathrm{B})$. The 5-year disease-specific survival rates were 93, 54, 41 and 28\%; and recurrence rates were $39,72,75$ and $91 \%$ for group I, II, III, IV patients respectively. 
A

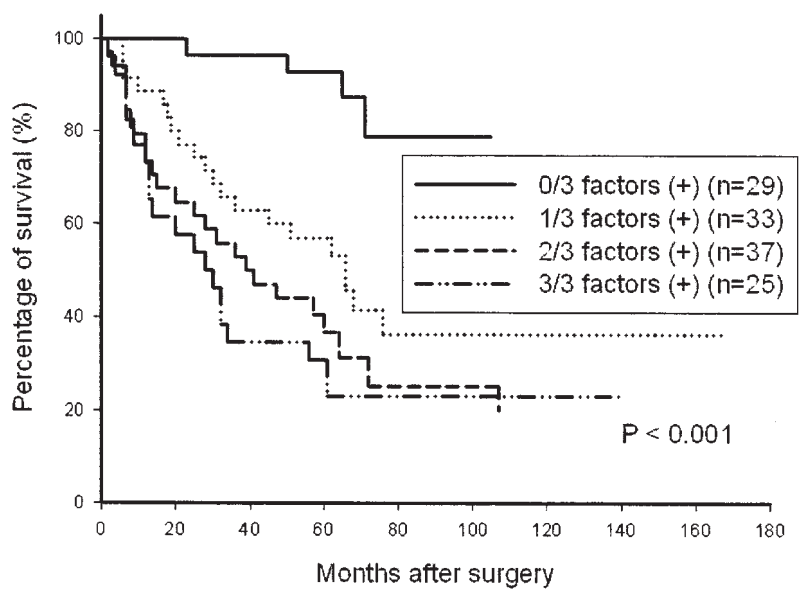

B

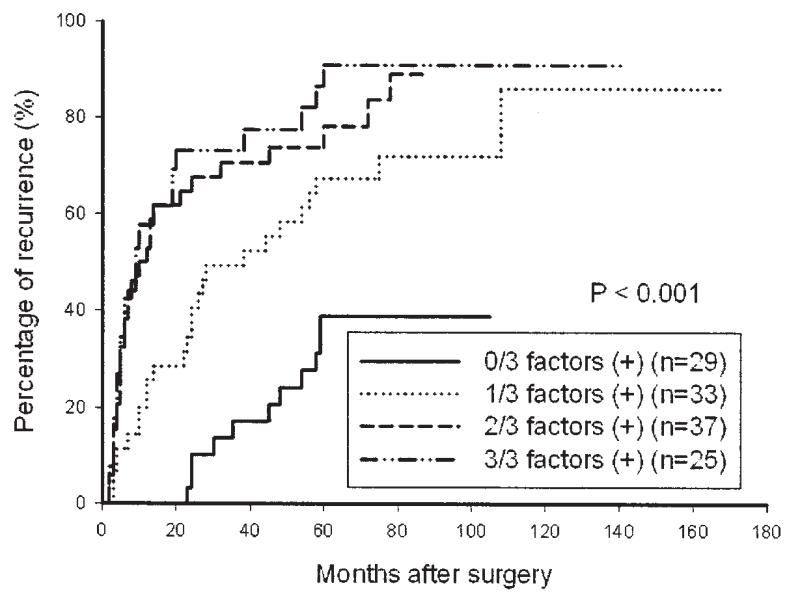

Figure 3. Combination of three expression patterns (PTEN down-regulation (+); p53 (+); high PCNA LI) to explore their prognostic significance in HCC and divide all the patients into four groups for comparison as i) none of three factors present (29 cases); ii) one of three factors present (33 cases); iii) two of three factors present ( 37 cases); and iv) all three factors present ( 25 cases). Patients in group I had the longest disease-specific survival ( $(\mathrm{P}<0.001$; Fig. $3 \mathrm{~A})$ and the latest disease recurrence ( $\mathrm{P}<0.001$; Fig. 3B), followed by group II, group III and group IV accordingly. $\mathrm{n}$, the number of patients in each group.

Table IV. Correlation of clinicopathological factors and disease recurrence of HCC.

\begin{tabular}{|c|c|c|c|c|c|c|}
\hline & \multicolumn{3}{|c|}{ Univariate } & \multicolumn{3}{|c|}{ Multivariate } \\
\hline & Risk & $95 \% \mathrm{CI}$ & $\mathrm{P}$ & Risk & $95 \% \mathrm{CI}$ & $\mathrm{P}$ \\
\hline \multicolumn{7}{|l|}{ Biomarkers } \\
\hline PTEN & 2.20 & $1.43-3.37$ & $<0.001^{\mathrm{a}}$ & - & - & - \\
\hline $\mathrm{p} 53$ & 1.63 & $1.07-2.49$ & $0.023^{\mathrm{a}}$ & - & - & - \\
\hline PCNA & 3.51 & $1.89-6.51$ & $<0.001^{\mathrm{a}}$ & - & - & - \\
\hline PTEN+p53+PCNA & 3.73 & $1.97-7.06$ & $<0.001^{\mathrm{a}}$ & 1.50 & $1.20-1.88$ & $<0.001^{\mathrm{a}}$ \\
\hline \multicolumn{7}{|l|}{ Clinical parameters } \\
\hline Age & 0.79 & $0.51-1.22$ & NS & - & - & - \\
\hline Gender & 0.82 & $0.52-1.63$ & NS & - & - & - \\
\hline$\alpha \mathrm{FP}$ & 2.83 & $1.82-4.39$ & $<0.001^{\mathrm{a}}$ & 2.52 & $1.60-3.99$ & $<0.001^{\mathrm{a}}$ \\
\hline HBV & 1.29 & $0.79-2.09$ & NS & - & - & - \\
\hline $\mathrm{HCV}$ & 0.93 & $0.57-1.52$ & NS & - & - & - \\
\hline Cirrhosis & 1.32 & $0.84-1.95$ & NS & - & - & - \\
\hline \multicolumn{7}{|c|}{ Pathological parameters } \\
\hline Tumor capsule & 2.24 & $0.35-0.85$ & $0.008^{\mathrm{a}}$ & 1.34 & $1.04-2.20$ & $0.033^{\mathrm{a}}$ \\
\hline Tumor size & 1.59 & $1.04-2.45$ & $0.032^{\mathrm{a}}$ & - & - & - \\
\hline Tumor number & 1.32 & $0.83-2.13$ & NS & - & - & \\
\hline Pathological stages & 3.20 & $2.05-5.01$ & $0.001^{\mathrm{a}}$ & 2.20 & $1.36-3.56$ & $0.001^{\mathrm{a}}$ \\
\hline Grade & 1.49 & $1.10-2.02$ & $0.009^{\mathrm{a}}$ & - & - & - \\
\hline
\end{tabular}

PTEN, down-regulation (-) or down-regulation (+); p53, positive or negative; PCNA, high or low (by ROC curve); PTEN+p53+PCNA, none or with; Age, $\geq 60$ or $<60$ years; Gender, male or female; serum $\alpha$-FP, $\geq 400$ or $<400$; HBV+, with or without; HCV+, with or without; Cirrhosis, with or without; Tumor capsulation, with or without; Tumor size, $\geq 5$ or $<5 \mathrm{~cm}$; Tumor number, solitary or $\geq 2$; Grades, I+II or III+IV; Pathologic stages, I+II or III+IV. aP $<0.05$.

Univariate and multivariate analysis of prognostic factors for HCC. To evaluate the potential of using PTEN, p53 and PCNA expression for the prognosis of HCC patients after surgery, univariate and multivariate analysis in the Cox proportional hazard model revealed that PTEN expression, serum $\alpha \mathrm{FP}$, pathologic stages and tumor capsule were independent variables to predict tumor recurrence $(\mathrm{P}<0.05)$ (Table IV) and PTEN expression, PCNA LI, pathologic stage, and tumor capsule to predict disease-specific survival $(\mathrm{P}<0.05)$ (Table $\mathrm{V})$. If we further put the variable of the combination of PTEN+p53+PCNA into multivariate analysis, this combination provides a more powerful prediction of disease recurrence and survival independently instead of single PTEN or PCNA factor (Tables IV and V). These results concluded that the combination of the three genes served as a more powerful prognostic factor than any of the 
Table V. Correlation of clinicopathological factors and disease-specific survival of HCC.

\begin{tabular}{|c|c|c|c|c|c|c|}
\hline & \multicolumn{3}{|c|}{ Univariate } & \multicolumn{3}{|c|}{ Multivariate } \\
\hline & Risk & $95 \% \mathrm{CI}$ & $\mathrm{P}$ & Risk & $95 \% \mathrm{CI}$ & $\mathrm{P}$ \\
\hline \multicolumn{7}{|l|}{ Biomarkers } \\
\hline PTEN & 2.31 & $1.42-3.76$ & $0.001^{\mathrm{a}}$ & - & - & - \\
\hline p53 & 1.90 & $1.17-3.09$ & $0.009^{\mathrm{a}}$ & - & - & - \\
\hline PCNA & 3.51 & $1.89-6.51$ & $<0.001^{\mathrm{a}}$ & - & - & - \\
\hline $\mathrm{PTEN}+\mathrm{p} 53+\mathrm{PCNA}$ & 1.83 & $1.44-2.83$ & $<0.001^{\mathrm{a}}$ & 1.64 & $1.27-2.13$ & $<0.001^{\mathrm{a}}$ \\
\hline \multicolumn{7}{|l|}{ Clinical parameters } \\
\hline Age & 0.83 & $0.53-1.31$ & NS & - & - & - \\
\hline Gender & 0.67 & $0.63-1.65$ & NS & - & - & - \\
\hline$\alpha \mathrm{FP}$ & 2.13 & $1.30-3.49$ & $0.003^{\mathrm{a}}$ & - & - & - \\
\hline HBV & 1.42 & $0.85-2.38$ & NS & - & - & - \\
\hline $\mathrm{HCV}$ & 0.69 & $0.41-1.19$ & NS & - & - & - \\
\hline Cirrhosis & 1.22 & $0.78-1.91$ & NS & - & - & - \\
\hline \multicolumn{7}{|c|}{ Pathological parameters } \\
\hline Tumor capsule & 2.13 & $0.24-0.60$ & $0.001^{\mathrm{a}}$ & 1.74 & $1.00-3.02$ & $0.043^{\mathrm{a}}$ \\
\hline Tumor size & 1.68 & $1.03-2.74$ & $0.038^{\mathrm{a}}$ & - & - & - \\
\hline Tumor number & 1.29 & $0.86-2.26$ & NS & - & - & - \\
\hline Pathological stages & 1.91 & $1.47-2.47$ & $<0.001^{\mathrm{a}}$ & 2.92 & $1.60-5.34$ & $<0.001^{\mathrm{a}}$ \\
\hline Grade & 1.63 & $1.15-2.30$ & $0.006^{\mathrm{a}}$ & - & - & - \\
\hline
\end{tabular}

PTEN, down-regulation (-) or down-regulation (+); p53, positive or negative; PCNA, high or low (by ROC curve); PTEN+p53+PCNA, none or with; Age, $\geq 60$ or $<60$ years; Gender, male or female; serum $\alpha-\mathrm{FP}, \geq 400$ or $<400$; HBV+, with or without; HCV+, with or without; Cirrhosis, with or without; Tumor capsule, with or without; Tumor size, $\geq 5$ or $<5 \mathrm{~cm}$; Tumor number, solitary or $\geq 2$; Grades, I+II or III+IV; Pathological stages, I+II or III+IV. aP $<0.05$.

individual genes. HCC patients with PTEN down-regulation $(+)$, p53 (+) and high PCNA LI in tissues had the most unfavorable outcome.

\section{Discussion}

In the present study, we provided evidence for down-regulated PTEN protein expression in $43 \%$ and p53 overexpression in about $42 \%$ of HCC samples and the diagnostic value of PTEN down-regulation and p53 over-expression as prognostic factors for HCC patients after surgery. These findings suggested that PTEN down-regulation and p53 over-expression frequently occur in HCC and may constitute prognostic indicators for HCC patients after surgery. Furthermore, the combination of three factors (PTEN, p53 and PCNA) provided a more powerful prediction of patient outcome than the individual factors. Two tumor suppressor genes were also demonstrated to correlate the proliferating states (PCNA) in HCC, which was a well known prognostic factor for HCC patients.

Proliferating cell nuclear antigen is an auxiliary protein present during G1-late phase and S phase. The increased PCNA LI of hepatocellular carcinoma closely correlated with both the advanced histologic grades and pathologic stages and poor patient outcome $(12,13)$. P53, a tumor suppressor gene, has an important function in DNA repair and in the regulation of apoptosis. Mutations of p53 were described in malignant tumors and can be the cause of the alterations of this balance. The correlation between p53 and PCNA expression in HCC has been reported $(9,10)$. In general, p53 positivity correlates with increased PCNA labeling index in HCC and represented advanced disease states and poor outcome. In the present study, we found p53 (+) tumors exhibit a higher PCNA index than p53 (-) tumors $(80 \%$ vs. $64 \%, \mathrm{P}<0.001)$, which was consistent with previous reports. It can be explained by the fact that the cyclin-dependent kinase inhibitor p21/WAF1 is regulated by $\mathrm{p} 53$-dependent and $\mathrm{p} 53$-independent pathways. In addition, p21/WAF1 binds with PCNA and inhibits the action of PCNA (28). Over-expression of p53 on immunostaining (mostly p53 mutation) can disturb this pathway and trigger PCNA activity, thereby promoting cancer cell proliferation. In this study, we also provided the first evidence that tumors with PTEN down-regulation exhibited a higher PCNA index (77\% vs. 67\%, $\mathrm{P}=0.014)$. Loss of PTEN function may accelerate tumor proliferation. However, the pathway of interaction between PTEN and PCNA was not reported and remains to be further elucidated.

PTEN can be inactivated through a wide range of mechanisms such as somatic mutations, hemizygous deletions, promoter methylation, decreased transcription/translation, increased protein degradation/phosphorylation, and differential subcellular compartmentalization (29-33). Functional PTEN expression was shown to suppress the growth and invasive properties of cancer cells, thereby enhancing the survival outcome in many types of tumors (34-38). Therefore, it was hypothesized that the loss of PTEN expression might influence the probability of survival and prognosis of HCC patients. In the present study, we identified $\sim 43 \%$ of HCC cases with down-regulated PTEN levels by immunohistochemistry. Previous studies indicated that somatic mutation in the PTEN gene was a rare event in HCC samples $(<5 \%)(19,20,22,23)$ and suggested that gene mutation is not the primary mechanism for PTEN 
inactivation in HCC. Allelic loss was proposed as the primary pathway for PTEN inactivation in many types of human cancers $(39,40)$. In HCC, the frequency of loss of flanking markers around PTEN allele was determined at $27 \%$ ( 25 out of 89 cases) and $32 \%$ (12 out of 37 cases), respectively $(19,20)$. The frequency of PTEN down-regulation $(\sim 40 \%)$ in the present study was in a closer range to that of allele loss $(27-32 \%)$ rather than that of gene mutation $(<5 \%)$. However, we did not exclude the probable existence of other mechanisms for PTEN inactivation in HCC.

The loss of PTEN alleles appears to be related to the lack of functional p53, which normally maintains chromosomal stability. A p53-binding element was identified in the promoter region of PTEN gene (25), indicating that p53 may activate PTEN gene expression. There is evidence indicating that PTEN inhibits PI3K/Akt signaling and promotes degradation of Mdm2, thereby increasing the cellular content and transactivation of the p53 (27). Other evidence indicated that hepatitis B Virus X ( $\mathrm{HBx})$ protein disrupts $\mathrm{p} 53$-mediated PTEN transcription, as the binding of the p53 protein to $\mathrm{p} 53$ binding site-oligo of PTEN promoter is decreased in HBXtransfected liver cells (26). Mice deficient of PTEN developed skin papilloma within 6 weeks after a single exposure to DMBA, indicating that loss of PTEN has a tumor-promoting effect (41). Accumulation of p53 protein and up-regulation of p53 targets were delayed in PTEN-knockout skin (41). These observations suggest that PTEN is involved in rapid recruitment of p53 in the tumor initiation phase and might thereby disturb the normal cell cycle, then enhancing tumor growth. We restored PTEN expression in PTEN-deficient hepatoma cells by adenovirus gene delivery, which led to the reduction of Akt/PKB phosphorylation, tumorigenicity, and invasive properties in hepatoma cells. Furthermore, the administration of PTEN gene delivery vectors effectively reduced tumor growth and prolonged the survival rates of mice bearing HCC (unpublished data). These data indicate that PTEN gene delivery may be applicable to treat HCC.

Considering that the combination of PTEN, p53 and PCNA provided a more powerful prediction of HCC outcome than the individual genes, we herewith propose that both tumor suppressor genes PTEN and p53 play an important role during liver carcinogenesis with interaction and enhance tumor cell proliferation (PCNA). They may possess diagnostic and therapeutic potentials for $\mathrm{HCC}$ in the future.

\section{Acknowledgements}

This study was supported in part by grants from the National Science Council, Taiwan (NSC 93-2314-B-182A-145- to T.-H.H).

\section{References}

1. Wands JR and Blum HE: Primary hepatocellular carcinoma. N Engl J Med 325: 729-731, 1991.

2. Okuda K: Hepatocellular carcinoma. J Hepatol 32: 225-237, 2000.

3. Ozturk M: Genetic aspects of hepatocellular carcinogenesis. Semin Liver Dis 19: 235-242, 1999.

4. Ng IO, Lai EC, Chan AS and So MK: Overexpression of p53 in hepatocellular carcinomas: a clinicopathological and prognostic correlation. J Gastroenterol Hepatol 10: 250-255, 1995.
5. Jeng KS, Sheen IS, Chen BF and Wu JY: Is the p53 gene mutation of prognostic value in hepatocellular carcinoma after resection? Arch Surg 135: 1329-1333, 2000.

6. Teramoto T, Satonaka K, Kitazawa S, Fujimori T, Hayashi K and Maeda S: p53 gene abnormalities are closely related to hepatoviral infections and occur at a late stage of hepatocarcinogenesis. Cancer Res 54: 231-235, 1994.

7. Nishida N, Fukuda Y, Kokuryu H, Toguchida J, Yandell DW, Ikenega $\mathrm{M}$, Imura $\mathrm{H}$, et al: Role and mutational heterogeneity of the p53 gene in hepatocellular carcinoma. Cancer Res 53: 368-372, 1993.

8. Bressac B, Galvin KM, Liang TJ, Isselbacher KJ, Wands JR and Ozturk M: Abnormal structure and expression of p53 gene in human hepatocellular carcinoma. Proc Natl Acad Sci USA 87: 1973-1977, 1990.

9. Itoh T, Shiro T, Seki T, Nakagawa T, Wakabayashi M, Inoue K and Okamura A: Relationship between p53 overexpression and the proliferative activity in hepatocellular carcinoma. Int J Mol Med 6: 137-142, 2000.

10. Nakopoulou L, Janinis J, Giannopoulou I, Lazaris AC, Koureas A and Zacharoulis D: Immunohistochemical expression of p53 protein and proliferating cell nuclear antigen in hepatocellular carcinoma. Pathol Res Pract 191: 1208-1213, 1995.

11. Bravo R, Frank R, Blundell PA and Macdonald-Bravo H: Cyclin/PCNA is the auxiliary protein of DNA polymerase-delta. Nature 326: 515-517, 1987

12. Kitamoto M, Nakanishi T, Kira S, Kawaguchi M, Nakashio R, Suemori S, Kajiyama G, et al: The assessment of proliferating cell nuclear antigen immunohistochemical staining in small hepatocellular carcinoma and its relationship to histologic characteristics and prognosis. Cancer 72: 1859-1865, 1993.

13. Adachi E, Hashimoto $\mathrm{H}$ and Tsuneyoshi M: Proliferating cell nuclear antigen in hepatocellular carcinoma and small cell liver dysplasia. Cancer 72: 2902-2909, 1993.

14. Li J, Yen C, Liaw D, Podsypanina K, Bose S, Wang SI, Puc J, et al: PTEN, a putative protein tyrosine phosphatase gene mutated in human brain, breast, and prostate cancer [see comments]. Science 275: 1943-1947, 1997.

15. Li DM and Sun H: TEP1, encoded by a candidate tumor suppressor locus, is a novel protein tyrosine phosphatase regulated by transforming growth factor beta. Cancer Res 57 : 2124-2129, 1997

16. Steck PA, Pershouse MA, Jasser SA, Yung WK, Lin H, Ligon AH, Langford LA, et al: Identification of a candidate tumour suppressor gene, MMAC1, at chromosome 10q23.3 that is mutated in multiple advanced cancers. Nat Genet 15: 356-362, 1997.

17. Maehama T and Dixon JE: PTEN: a tumour suppressor that functions as a phospholipid phosphatase. Trends Cell Biol 9: 125-128, 1999.

18. Di Cristofano A and Pandolfi PP: The multiple roles of PTEN in tumor suppression. Cell 100: 387-390, 2000.

19. Kawamura N, Nagai H, Bando K, Koyama M, Matsumoto S, Tajiri T, Onda M, et al: PTEN/MMAC1 mutations in hepatocellular carcinomas: somatic inactivation of both alleles in tumors. Jpn J Cancer Res 90: 413-418, 1999.

20. Fujiwara Y, Hoon DS, Yamada T, Umeshita K, Gotoh M, Sakon M, Nishisho I, et al: PTEN / MMAC1 mutation and frequent loss of heterozygosity identified in chromosome 10q in a subset of hepatocellular carcinomas. Jpn J Cancer Res 91: 287-292, 2000.

21. Xu XR, Huang J, Xu ZG, Qian BZ, Zhu ZD, Yan Q, Cai T, et al: Insight into hepatocellular carcinogenesis at transcriptome level by comparing gene expression profiles of hepatocellular carcinoma with those of corresponding noncancerous liver. Proc Natl Acad Sci USA 98: 15089-15094, 2001

22. Yao YJ, Ping XL, Zhang H, Chen FF, Lee PK, Ahsan H, Chen CJ, et al: PTEN/MMAC1 mutations in hepatocellular carcinomas. Oncogene 18: 3181-3185, 1999

23. Yeh KT, Chang JG, Chen YJ, Chen ST, Yu SY, Shih MC, Perng LI, et al: Mutation analysis of the putative tumor suppressor gene PTEN/MMAC1 in hepatocellular carcinoma. Cancer Invest 18: 123-129, 2000.

24. Hu TH, Huang CC, Lin PR, Chang HW, Ger LP, Lin YW, Changchien CS, et al: Expression and prognostic role of tumor suppressor gene PTEN/MMAC1/TEP1 in hepatocellular carcinoma. Cancer 97: 1929-1940, 2003.

25. Stambolic V, MacPherson D, Sas D, Lin Y, Snow B, Jang Y, Benchimol S, et al: Regulation of PTEN Transcription by $\mathrm{p} 53$. Mol Cell 8: 317-325, 2001. 
26. Chung TW, Lee YC, Ko JH and Kim CH: Hepatitis B Virus X protein modulates the expression of PTEN by inhibiting the function of p53, a transcriptional activator in liver cells. Cancer Res 63: 3453-3458, 2003.

27. Mayo LD, Dixon JE, Durden DL, Tonks NK and Donner DB: PTEN protects p53 from Mdm2 and sensitizes cancer cells to chemotherapy. J Biol Chem 277: 5484-5489, 2002.

28. Qin LF, Ng IO, Fan ST and Ng M: p21/WAF1, p53 and PCNA expression and p53 mutation status in hepatocellular carcinoma. Int J Cancer 79: 424-428, 1998.

29. Perren A, Komminoth P, Saremaslani P, Matter C, Feurer S, Lees JA, Heitz PU, et al: Mutation and expression analyses reveal differential subcellular compartmentalization of PTEN in endocrine pancreatic tumors compared to normal islet cells. Am J Pathol 157: 1097-1103, 2000.

30. Gimm O, Perren A, Weng LP, Marsh DJ, Yeh JJ, Ziebold U, Gil E, et al: Differential nuclear and cytoplasmic expression of PTEN in normal thyroid tissue, and benign and malignant epithelial thyroid tumors. Am J Pathol 156: 1693-1700, 2000

31. Dahia PL, Aguiar RC, Alberta J, Kum JB, Caron S, Sill H, Marsh DJ, et al: PTEN is inversely correlated with the cell survival factor Akt/PKB and is inactivated via multiple mechanisms in haematological malignancies. Hum Mol Genet 8: 185-193, 1999.

32. Zhong H, Chiles K, Feldser D, Laughner E, Hanrahan C, Georgescu MM, Simons JW, et al: Modulation of hypoxiainducible factor 1alpha expression by the epidermal growth factor/phosphatidylinositol 3-kinase/PTEN/AKT/FRAP pathway in human prostate cancer cells: implications for tumor angiogenesis and therapeutics. Cancer Res 60: 1541-1545, 2000.

33. Vazquez F, Ramaswamy S, Nakamura N and Sellers WR: Phosphorylation of the PTEN tail regulates protein stability and function. Mol Cell Biol 20: 5010-5018, 2000.
34. Lee JI, Soria JC, Hassan KA, El-Naggar AK, Tang X, Liu DD, Hong WK, et al: Loss of PTEN expression as a prognostic marker for tongue cancer. Arch Otolaryngol Head Neck Surg 127: 1441-1445, 2001.

35. Tachibana M, Shibakita M, Ohno S, Kinugasa S, Yoshimura H, Ueda S, Fujii T, et al: Expression and prognostic significance of PTEN product protein in patients with esophageal squamous cell carcinoma. Cancer 94: 1955-1960, 2002.

36. McMenamin ME, Soung P, Perera S, Kaplan I, Loda M and Sellers WR: Loss of PTEN expression in paraffin-embedded primary prostate cancer correlates with high Gleason score and advanced stage. Cancer Res 59: 4291-4296, 1999.

37. Depowski PL, Rosenthal SI and Ross JS: Loss of expression of the PTEN gene protein product is associated with poor outcome in breast cancer. Mod Pathol 14: 672-676, 2001.

38. Sano T, Lin H, Chen X, Langford LA, Koul D, Bondy ML, Hess KR, et al: Differential expression of MMAC/PTEN in glioblastoma multiforme: relationship to localization and prognosis. Cancer Res 59: 1820-1824, 1999.

39. Suzuki A, de la Pompa JL, Stambolic V, Elia AJ, Sasaki T, del Barco Barrantes I, Ho A, et al: High cancer susceptibility and embryonic lethality associated with mutation of the PTEN tumor suppressor gene in mice. Curr Biol 8: 1169-1178, 1998

40. Marsh DJ, Dahia PL, Coulon V, Zheng Z, Dorion-Bonnet F, Call KM, Little R, et al: Allelic imbalance, including deletion of PTEN/MMACI, at the Cowden disease locus on 10q22-23, in hamartomas from patients with Cowden syndrome and germline PTEN mutation. Genes Chromosomes Cancer 21: 6169, 1998

41. Komazawa N, Suzuki A, Sano S, Horie K, Matsuura N, Mak TW, Nakano T, et al: Tumorigenesis facilitated by Pten deficiency in the skin: evidence of p53-Pten complex formation on the initiation phase. Cancer Sci 95: 639-643, 2004. 